\title{
Retrieving Divine Immensity and Omnipresence
}

\author{
ROSS D. INMAN
}

Immensus Pater, immensus Filius, immensus Spiritus Sanctus

-Athanasian Creed (Burn 1918: 101)

The divine attributes of immensity and omnipresence have been integral to classical Christian confession regarding the nature of the triune God. Divine immensity and omnipresence are affirmed in doctrinal standards such as the Athanasian Creed $(c$. 500), the Fourth Lateran Council (1215), the Council of Basel (1431-49), the Second Helvetic Confession (1566), the Westminster Confession of Faith (1647), the Second London Baptist Confession (1689), and the First Vatican Council (1869-70). In the first section of this chapter, I offer a brief historical overview of divine immensity and divine omnipresence in the Christian tradition. I then offer a brief taxonomy of contemporary models of divine omnipresence in the philosophical and theological landscape. In the second, more constructive section, I aim to gesture toward the retrieval of several classical insights regarding immensity and omnipresence that remain unexplored in contemporary analytic work.

\section{DIVINE IMMENSITY AND OMNIPRESENCE: HISTORICAL LANDSCAPE}

In the Christian theological tradition, divine immensity and omnipresence have largely been understood to be distinct yet intimately related divine attributes. Divine immensity has been closely associated with divine infinity, where divine infinity has traditionally been understood in negative terms as God's being without limitation of any kind, whether in essence, power, knowledge, wisdom, goodness, and so on (Eph. 3:20; Isa. 40:12, 15, 17). In positive terms, God is understood to be qualitatively infinite in that the divine nature is intrinsically full and complete in the eternal, divine processions of paternity, filiation, and spiration. It is precisely because of the absolute fullness and plenitude of the triune God ad intra (Ps. 145:3) that there are no finite bounds to the range of God's gratuitous relations to creatures ad extra (Job 11:7-8; Isa. 40:12, 15; Dan. 4:34; Eph. $1: 19,2: 7)$.

To say that God is immense, then, is to say that the divine nature is without limitation, particularly as it pertains to the limitations of space; the divine nature is uncircumscribable, immeasurable, and incapable of being contained or bound by space. Being qualitatively 
and positively infinite, God categorically transcends-and is entirely unconditioned by-spatial limitations and boundaries due to the intrinsic fullness of the divine life (correlatively, divine eternity has been classically understood as the infinity of the divine nature with respect to time or duration). ${ }^{1}$ Hillary of Poitiers (ad 300-368) summarizes this close connection between divine infinity and immensity as follows: God is "infinite, for nothing contains Him and He contains all things; He is eternally unconditioned by space, for He is illimitable" (Poitiers 1994: 2.6). ${ }^{2}$

As a corollary of divine infinity, and in contrast to divine omnipresence, immensity has been taken to be an absolute, that is, non-relational, divine attribute. God ad intra, apart from his relation to creation, is immense in his essence. ${ }^{3}$ Divine immensity entails that not only is the triune God not conditioned or limited by space, but also that this fact positively indicates "the boundless liberty of God to be and act as he determines in relation to space. Immensity concerns the plenitude, richness, sufficiency and effectiveness of God and so of God's disposition of himself in relation to creaturely space" (Webster 2016a: 93). The attribute of divine omnipresence, however, has historically been understood to be a relative divine attribute predicated on God's works ad extra in relation to created space and its occupants; God is omnipresent purely in relation to created, spatial reality (Bavinck 2004: 168).

Common scriptural passages cited in favor of divine immensity and omnipresence include Ps. 139:7-10, Jer. 23:24, 1 Kgs 8:23, 27, Acts 17, and Isa. 66:1. These scriptural texts emphasize both divine ubiquity, that the divine essence itself is everywhere present throughout space, as well as divine immensity, that the divine essence cannot be contained or limited by space.

The immensity of God is underscored in Solomon's theologically rich prayer at the temple dedication, "O Lord, God of Israel, there is no God like you, in heaven above or on earth beneath ... But will God indeed dwell on the earth? Behold, heaven and the highest heaven cannot contain you; how much less this house that I have built" (1 Kgs $8: 23,27) .{ }^{4}$ The contrast between the immense, Holy One of Israel and the circumscribed gods of the nations is clear and deliberate; it is impossible for any created place to contain the true and living God of Israel. God, as immense and the ultimate source of all nondivine reality, is Lord of all spatial reality and thus cannot be contained by space (Isa. $66: 1$ ). Along similar lines, and perhaps echoing Solomon's prayer of dedication, the Apostle Paul weds the sheer plenitude of God as the limitless creator and sustainer of all with God's inability to be contained by place, "The God who made the world and everything in it, being Lord of heaven and earth, does not live in temples made by man,

\footnotetext{
${ }^{1}$ Arminius (1986: IV, XV-XVI) summarizes the classic view nicely: "From the simplicity and infinity of the divine essence, arise infinity with regard to time, which is called 'Eternity'; and with regard to place, which is called 'Immensity.' "'

${ }^{2}$ For a sampling of patristic authors on immensity, see Clement of Alexandria (1885: 2.2); Athanasius (1982: 17); Cyril of Alexandria (1874: 1.9); John of Damascus (1958: 1.13); Augustine (1961: 7.20.26) and (1994: 4.4.5). For a sampling of medieval authors, see Anselm, Monologion (2007: chs. 14, 22); Aquinas (2012: Ia, qq. 7-8). ${ }^{3}$ See Turretin (1992); Muller (2003: 335-45); Webster (2016a: 93.). Leibniz (1989: 106), in his rich correspondence with Samuel Clarke on immensity and space, underscores this traditional idea as follows: "It is true that the immensity and eternity of God would subsist though there were no creatures, but those attributes would have no dependence either on times or places. If there were no creatures, there would be neither time nor place, and consequently no actual space. The immensity of God is independent of space."

${ }^{4}$ All Biblical quotations in this chapter are from the English Standard Version of the Bible.
} 
nor is he served by human hands, as though he needed anything, since he himself gives to all mankind life and breath and everything" (Acts 17:24-25).

Perhaps the most commonly cited scriptural text in the Christian dogmatic tradition in support of God's ubiquitous presence is Psalm 139: 7-10:

${ }^{7}$ Where shall I go from your Spirit?

Or where shall I flee from your presence?

${ }^{8}$ If I ascend to heaven, you are there!

If I make my bed in Sheol, you are there!

${ }^{9}$ If I take the wings of the morning

and dwell in the uttermost parts of the sea,

${ }^{10}$ even there your hand shall lead me, and your right hand shall hold me.

The Psalmist proceeds to recount that neither deep darkness (139: 11-12) nor the hidden place of a mother's womb can escape the divine presence (vv. 13-16). Through the prophet Jeremiah, God addresses the deceptive prophets of Israel who attempt to remove themselves from the council of the Lord by saying, "Am I a God at hand, declares the Lord, and not a God far away? Can a man hide himself in secret places so that I cannot see him? declared the Lord. Do I not fill heaven and earth? declares the Lord" (Jer. 23:23-24).

Historically, dogmatic reflection on divine omnipresence in the Christian tradition has taken the form of the following threefold schema: God is everywhere by (1) essence, (2) power, and (3) presence. ${ }^{5}$ This threefold schema has been central to patristic, medieval, post-Reformation, and early modern Christian theological inquiry concerning divine omnipresence. ${ }^{6}$ In his Sentences, what was once the standard university text in Western medieval theology, Peter Lombard synthesized previous theological work on divine omnipresence as follows: "And so it is to be known that God, existing ever unchangeably in himself, by presence, power, and essence is in every nature or essence without limitation of himself, and in every place without being bounded, and in every time without change" (Lombard 2007: bk. 1, d. 37, ch. 1). While there have been a variety of ways of explicating this threefold schema in the history of Christian dogmatics, one standard way to gloss tenets (2) and (3) has been in terms of God's being everywhere by way of divine activity and operation, that is, (1), and everywhere by way of divine knowledge, that is, (3), respectively. That is, God is everywhere by his power and operation insofar as God creates, sustains, and governs all spatial creatures (Acts 17:28). Moreover, God is also everywhere by presence, that is, (3), precisely because God is directly cognitively aware of each and every spatial creature and creaturely event (Heb. 4:13). ${ }^{7}$ Here it is important to underscore that tenet (1), God's ubiquitous presence by essence, has traditionally been distinguished from tenets (2) and (3), that is, God's ubiquitous presence by power and knowledge. The divine essence or substance itself, not merely the divine power or the divine knowledge, is present to each and every place in space.

${ }^{5}$ The schema is often thought to originate with Peter Lombard (2007: bk. 1, d. 17, ch. 1), but Lombard himself points out that it extends back to Gregory the Great's Commentary on the Song of Songs. See also Turretin (1992) and Aquinas (2012: Ia.Q8.a3) in particular.

${ }^{6}$ See Fuerst (1951) and Reynolds (1992).

${ }^{7}$ See Fuerst (1951) for a thorough treatment of how this threefold schema has been understood in the Christian tradition. 
Patristic, medieval, and post-Reformation theologians were largely in agreement about the precise mode of presence at work in divine omnipresence, how the divine essence is present at every point in space, that is, tenet (1). Classical theologians commonly distinguished three ways in which a being could be in or present at a place, whether a material being (e.g., body) or an immaterial being (e.g., God, angels, human souls). A clear statement of these various modes of presence-circumscriptive, definitive, and repletiveis offered (and endorsed) by Francis Turretin, in explicit reliance on the received medieval theological inheritance: ${ }^{8}$

Three modes of being in a place are commonly held: (1) circumscriptively—attributed to bodies because they are in a place and space so as to be commensurate with parts of space; (2) definitively-applicable to created spirits and incorporeal substances (which are defined by certain places, and are so here as not to be anywhere else); (3) repletively - which is ascribed to God because his immense essence is present with all and, as it were, completely fills all places. (Turretin 1992, my emphasis)

The core idea behind circumscriptive presence, a mode of presence that belongs exclusively to material beings, is that material beings are both composed of proper parts (and thus not mereologically simple) and are extended throughout a particular place by way of their having distinct proper parts "spread out" across the place in question. My body, for example, is circumscriptively present at a place $P$ in virtue of its having distinct proper parts (head, hands, heart, etc.) that are themselves present at the distinct sub-places, $p s$, of $P$. While my entire body is wholly present at $P$, my body is partly located where my right arm is, and partly located where my head is, and so on. More carefully, following William of Ockham (1991), "What is circumscriptively in a place is a thing which is such that (i) a part of it is in a part of the place and (ii) the whole of it is in the whole of the place" (my emphasis). In this way, that which is circumscriptively present at a place is circumscribed by and contained in the place in question; while my body can be partly present at distinct places at the same time, it is incapable of being wholly present (without remainder) at distinct places at one and the same time (it cannot simultaneously be wholly multi-located).

Definitive presence is the mode of presence that uniquely characterizes spiritual creatures, both angels and human souls, insofar as they are both non-composite (and thus mereologically simple) and limited in nature; what is devoid of proper parts cannot be circumscriptively present at a place and thus cannot be partly present at distinct places at the same time. ${ }^{9}$ Rather, angels and humans souls can be said to be at a place in virtue of being wholly present at a place $P$ as well as wholly present at every distinct sub-place, $p s$, of $P$. Where material beings are capable of being wholly present at only a single place at a time, immaterial beings are able to be wholly present at distinct places at the same time. Again, as Ockham (1991) puts it, "a thing is definitively in a place when (i) the whole of it is in the whole place and not outside the place and (ii) the whole of it is in each part of

\footnotetext{
${ }^{8}$ The distinction between circumscriptive, definitive, and repletive presence was a staple of patristic, medieval, and post-Reformation reflection on the relationship between spiritual and material creation. See John of Damascus (1958: 1, c.13); William of Ockham (1991); Augustine (2004: 187, 4.11); Lombard (2007: bk. 1, d. 37 n. 6); and Anselm (2007: ch. 21) for a concise statement of each of these modes of spatial presence in the Latin West, and Turretin (1992) for a representative work in the post-Reformation period.

${ }^{9}$ Robert Pasnau (2011a: 18) uses the terms "meremeric existence" and "holenmeric existence" in the place of the more traditional terminology of circumscriptive and definitive presence, respectively.
} 
the place." However, like created material beings, created spiritual beings like angels and human souls are bound and contained by the places where they are present insofar as their natures are finite and limited. Spiritual creatures, as Turretin puts it above, "are defined by certain places, and are so here as not to be anywhere else." While my immaterial soul, for example, can be wholly present in the whole of my body and wholly present in each part of my body, it cannot be wholly present at some distinct place where my body is not present (e.g., a white sandy beach in Bermuda).

Finally, God alone is repletively present in so far as the divine essence, being spiritual, infinite, and immense, is capable of being wholly present at each and every place at the same time. ${ }^{10}$ As a mereological simple, the ubiquity of the divine essence, that is, tenet (1) of the threefold schema, is not to be glossed in terms of circumscriptive presence. Yet as infinite, immense, and neither contained nor bound by any place whatsoever, the ubiquitous presence of the divine essence is not to be glossed in terms of definitive presence either; the divine essence is wholly present to each existing place at the same time, yet bound by none. Augustine (2004) articulates and contrasts this unique mode of ubiquitous divine presence-repletive presence-with circumscriptive and definitive presence as follows:

Yet he is not spread out in space like a mass such that in half of the body of the world there is half of him and half of him in the other half, being in that way whole in the whole. Rather, he is whole in the heavens alone and whole on the earth alone and whole in the heavens and in the earth, contained in no place, but whole everywhere in himself. (Letter 187, 4.11).)

Note that the differences between the above modes of presence concern a difference in kind as well as degree. In contrast to definitive and repletive presence, circumscriptive presence is a distinct kind of presence at a place insofar as it is defined in terms of mereological extension, having proper parts distributed across distinct places. Definitive and repletive presence, however, arguably differ only in degree. ${ }^{11}$ Thomas Aquinas, for instance, states that both the human soul and God are similarly present in the places where they are located, "just as the soul is whole in each part of the body, so God is whole in all things and in each thing” (2012: Ia.Q8.a2.ad3). ${ }^{12}$

\section{DIVINE OMNIPRESENCE: CONTEMPORARY LANDSCAPE}

With the above historical framework in place, I now want to present a brief taxonomy of contemporary models of divine omnipresence as found in recent analytic philosophical and theological literature. At the very least, extant theological and philosophical models of divine omnipresence agree on the following: to say that God is omnipresent is to say

\footnotetext{
${ }^{10}$ Thomas Aquinas (2012: Ia, q. 8, a. 4) would qualify this by saying that God alone is repletively present both primarily (the divine nature itself is wholly present everywhere and not some proper part of the divine nature) and per se (i.e., God "is not everywhere accidentally, on the basis of an assumed condition").

${ }^{11}$ This is not to say that the metaphysical grounds in virtue of which God is repletively present, viz. God's immensity (a corollary of divine infinity), does not differ qualitatively from the grounds in virtue of which created spirits are definitively present. My point here is that repletive presence per se differs from definitive presence only in degree, not kind.

${ }^{12}$ See also William T. Shedd (2003: 278), "The omnipresence of God is not by extension, multiplication, or division of essence. He is all in every place, similarly as the soul is all in every part of the body. The whole essence of God is here, is there, and everywhere."
} 
that God is present to or located at each and every place. The individual models differ in how they characterize the precise nature of ubiquitous divine presence.

In a previous work (2017), I characterized two distinct notions of location or presencederivative and fundamental - and defined two general models of divine omnipresence accordingly. ${ }^{13}$ Here I want to modify slightly those previous definitions to make them conducive to those with more classical theistic sensibilities concerning the divine nature. ${ }^{14}$ Taking "is present at" as primitive, we can explicate these two varieties of presence as follows (where " $p$ " stands for some place):

Fundamental Presence: $x$ is present at $p$ fundamentally $={ }_{\mathrm{df}} x$ is present at $p$ but not solely in virtue of standing in causal and/or epistemic relation(s), $\mathrm{R}(\mathrm{s})$, to some distinct entity, $y$, that is present at $p$.

Derivative Presence: $x$ is present at $p$ derivatively $={ }_{\mathrm{df}} x$ is present at $p$ solely in virtue of standing in some causal and/or epistemic relation(s), R(s), to some distinct entity, $y$, where $y$ is present at $p$ fundamentally.

Material objects, for example, are plausibly construed as being present at their respective places in the fundamental sense. Trees, tables, and tigers are present at a place, but not simply in virtue of being causally related to something that is itself present at a place. However, something may be present to a place by way of standing in some causal or epistemic relation to something that is itself present at a place, for example, my being cognitively aware of or in causal contact with things and events at a place.

It is important to note that a thing's being derivatively present at a particular place is nothing more than its standing in some causal and/or epistemic relation(s) to a distinct thing that is itself present at a place in the fundamental sense. By contrast, a thing's being present at a place in the fundamental sense amounts to the claim that its being present somewhere cannot be reduced to its standing in a causal and/or epistemic relation $\mathrm{R}$ to a distinct thing $y$ that is present at a place in the fundamental sense.

With the above definitions of fundamental and derivative presence in hand, we can define two general models of divine omnipresence as follows. Let " $\mathrm{P}_{\mathrm{d}}$ " stand for derivative presence, " $\mathrm{P}_{\mathrm{f}}$ " for fundamental presence, and read " $\mathrm{P}(\mathrm{God}, p)$ " as "God is present at $p$ " (Inman 2017):

(DO) Derivative Omnipresence: $(\forall p)\left(p\right.$ is a place $\left.\rightarrow \mathrm{P}_{\mathrm{d}}(\mathrm{God}, p)\right)$

For every place, $p$, God is derivatively present at $p$.

(FO) Fundamental Omnipresence: $(\forall p)\left(p\right.$ is a place $\left.\rightarrow \mathrm{P}_{\mathrm{f}}(\mathrm{God}, p)\right)$

For every place $p$, God is fundamentally present at $p$.

On a DO model, God is omnipresent by being derivatively present at each and every place. An FO model, by contrast, maintains that God is omnipresent by being fundamentally present at each and every place; the divine nature is everywhere present but not solely in virtue of causal and/or epistemic contact with things present at a place

\footnotetext{
${ }^{13} \mathrm{My}$ (2017) paper on divine omnipresence was accepted for publication in 2014 but was widely circulated as "forthcoming" for several years until its 2017 publication in the eighth volume of Oxford Studies in Philosophy of Religion.

${ }^{14}$ The prior formulation of fundamental presence entailed that God's fundamental ubiquitous presence is intrinsic to God (God being present to every place in his own right, i.e., non-relationally), which cuts against a robust understanding of divine aseity and simplicity, the latter affirming that God is strictly identical to whatever God is intrinsically.
} 
in the fundamental sense. A rough and informal test for distinguishing a DO from an FO model would be if the model entails that God, considered apart from his bearing causal and/or epistemic relations to things that are themselves present at $p$ fundamentally, could nevertheless be present at $p$. If so, then you have an FO model; if not, then a DO model.

It is an oft-repeated claim in the contemporary literature that DO is arguably the classical model of divine omnipresence in the Christian tradition (Jedwab 2016). Individual DO models differ with respect to how they construe the particular causal and/ or epistemic relations ( $\mathrm{R}$ or Rs) in which God stands to entities that are present at a place in the fundamental sense. A widespread interpretation of Anselm of Canterbury (albeit incomplete, by my lights) characterizes $\mathrm{R}$ exclusively in epistemic or cognitive terms, namely, God's immediate knowledge or cognitive awareness of the goings on at every place. ${ }^{15}$ Likewise, many interpret Aquinas as explicating divine omnipresence principally in terms of God's directly causally sustaining in existence each and every creature at a place (Swinburne 1993; Cross 2003; Wainright 2010; Wierenga 2010). It is difficult to see how, on a DO model, omnipresence is a distinct divine attribute over and above divine omniscience, omnipotence, or God's providential and causal activity in creation. Consequently, the proponent of a DO model might think that divine omnipresence is ultimately reducible to or simply "nothing over and above" a range of distinct divine attributes or divine actions in relation to creatures.

The vast bulk of contemporary work on divine omnipresence in analytic philosophy and theology aims to explicate and defend a variant of DO. The likes of Richard Swinburne (1993), Charles Taliaferro (1994), Joshua Hoffman and Gary Rosenkrantz (2002), William Lane Craig and J. P. Moreland (2003), Edward Wierenga (2010), William Wainwright (2010), Joseph Jedwab (2016), James Arcadi (2017) and George Gasser (2019) all unpack Rs in terms of God's standing in immediate (basic) causal relations and/ or his immediate knowledge of the goings on at every place. ${ }^{16}$

Be that as it may, there are a handful of contemporary philosophers and theologians who favor a variant of an FO model of omnipresence, including Luco J. Van Den Brom (1993), Hud Hudson (2009, 2014), Robert Oakes (2006), Alexander Pruss (2013), Richard Cross (2016), Ross Inman (2017), and James Gordon (2018). Some have even argued that FO models have greater historical prominence than is standardly acknowledged. ${ }^{17}$ What unifies various FO models is that each affirms that God is present at every place but not simply in virtue of his standing in causal and/or epistemic relations to objects that are present at a place fundamentally. On an FO model, while God does indeed stand in causal and epistemic relations to spatial creatures that are present in the fundamental

\footnotetext{
${ }^{15}$ See Wierenga (1988), Blount (1997), and Hudson (2009). Although see Conn (2011), Leftow (1989), Pasnau (2011a), and Zagzebski (2013) for an alternative reading of Anselm on omnipresence.

${ }^{16}$ Although J. P. Moreland has expressed in personal conversation that he is inclined to adopt an FO model of omnipresence where God is wholly present at each region of space, akin to the way in which the immaterial human soul is wholly present at each part of the human body. The recent work of Eleonore Stump (2010, 2013, 2018) on divine omnipresence is a bit harder to classify. On the one hand, Stump appeals to the notion of shared or joint attention as a more fine-grained epistemic condition on divine presence, in addition to God's immediate causal activity and cognitive awareness. Yet Stump regularly speaks as if there are independent conditions that must obtain in order for God to stand in these epistemic relations to creatures. For example, Stump (2010: 117) says, "In order for God to be omnipresent, that is, in order for God to be always and everywhere present, it also needs to be the case that God is always and everywhere in a position to share attention with any creature able and willing to share attention with God" (my emphasis). The notion of being in a position to share attention with God suggests that omnipresence is not to be analyzed, at bottom, in terms of a DO model.

${ }^{17}$ See Pasnau (2011b), Cross (2016), and Inman (2017), in particular.
} 
sense, these relations are not exhaustive of nor most fundamental to the nature of divine omnipresence. Consequently, for those who defend a variant of FO, omnipresence is a distinct divine attribute and thus irreducible to omnipotence, omniscience, or God's providential and causal activity in creation (or a combination thereof). It is also important to note that the primary issue distinguishing FO and DO models is not whether God's ubiquitous presence is best understood in spatial or nonspatial terms. Indeed, one could adopt a DO model and maintain that the immediate causal relations in virtue of which God is everywhere present constitutes a genuine mode of spatial presence. ${ }^{18}$ Likewise, one could in principle adopt an FO model and hold that God is strictly aspatial, yet affirm that the way in which God is everywhere present is not exclusively constituted by causal and/or epistemic considerations. ${ }^{19}$

\section{TOWARD A RETRIEVAL OF DIVINE IMMENSITY AND OMNIPRESENCE}

In this next, more constructive section, I want to gesture toward the retrieval of several classical tenets of divine immensity and omnipresence in the Christian tradition. Though strictly distinct attributes, divine immensity and omnipresence have been traditionally thought to be closely connected in the following sense: it is precisely because the divine essence is infinite and immense ad intra that the divine essence is repletively present to each and every place ad extra, as per tenet (1) of the above threefold schema. On this classical picture, then, divine immensity is explanatorily prior to divine omnipresence; divine immensity is the principal metaphysical ground of God's repletive presence in creation. Along these lines, Turretin (1992: 197) states that repletive presence "is ascribed to God because his immense essence is present with all and, as it were, completely fills all places." Similarly, in his Public Disputations, Jacob Arminius (1986: IV, XV-XVI) summarizes this classical insight as follows: "Immensity is a pre-eminent mode of the Essence of God, by which it is void of place according to space and limits ... After creatures, and places in which creatures are contained, have been granted to have an existence, from this Immensity follows the Omnipresence or Ubiquity of the Essence of God."

Moreover, it is interesting to note that Aquinas treats omnipresence immediately after he discusses divine perfection and infinity in his Summa Theologiae. In his preliminary remarks to question 7 on "Divine Infinity," which immediately precedes the question "God's existence in things," Aquinas notes the explanatory ordering between divine infinity and omnipresence: "After considering divine perfection, the next topic that ought to be considered is God's infinity and God's existence in things, for it is said that God is everywhere and in all things in so far as God is unbounded and infinite" (Aquinas 2012: Ia.q.7). Perhaps the clearest articulation of the classical relationship between immensity and omnipresence is Turretin (1992: 201), echoing the medieval scholastics:

\footnotetext{
${ }^{18}$ Harm Goris (2009: 42), who interprets Aquinas's along the lines of what I am calling a DO model, states, "The only way spiritual beings can be in a place is by way of causality: by bringing about an effect in a body, they become located in space." Jeffrey Brower (personal correspondence) has also suggested a reading of Aquinas on omnipresence along the lines of DO, yet one where God's ubiquitous presence is strictly spatial.

${ }^{19}$ One option here, taken by Turretin (1992: 198) and other Reformed Scholastics, is by way of via negativa, that the precise manner in which the divine essence is everywhere present is ultimately not "in the multiplication of the divine essence ... in the extension and diffusion of any corporeal mass ... or in physical contact.”
} 
Although the immensity and the omnipresence of God are always connected together, yet they admit of distinction. The former indicates an absolute property belonging to him from eternity; the latter, based upon it, denotes a habitude to place existing in time. They are related to each other as a first and second act or a principle (principia) and a principiate (principiati). For out of immensity arises omnipresence, which supposes immensity as its foundation. God is therefore omnipresent because he is immense.

Consequently, failing to note the explanatory posteriority of God's ubiquitous presence ad extra to the full and immense life of the triune God ad intra yields a theologically truncated model of divine omnipresence. ${ }^{20}$

Second, despite its widespread acceptance among contemporary philosophers and theologians, there is significant historical precedent for rejecting the view that divine omnipresence is "nothing over and above" God's ubiquitous (direct) causal activity and/or knowledge. There is strong representation in the Christian tradition for the view that divine omnipresence is not exhausted by tenets (2) and (3) of the classical threefold schema, that is, divine power and presence (i.e., knowledge). ${ }^{21}$ So much so that Francisco Suarez can summarize the preceding consensual Christian tradition regarding divine omnipresence (including immensity as the principal metaphysical ground of omnipresence) in the following manner: "God is intimately present to this corporeal universe, not just by presence (that is, cognitively) and by power or action, but also by his essence or substance, just as all the theologians teach, as certain to the faith, on account of divine immensity."22

This fuller account of divine omnipresence within the Christian tradition stands in sharp contrast to the near universal bent in the contemporary literature to characterize omnipresence as "nothing over and above" God's immediate causal activity or knowledge. Consequently, in explicating divine omnipresence in this reductive manner, the majority of contemporary models have contracted divine omnipresence to tenets (2) and/or (3) of the classical, threefold schema. But this is to neglect an integral and essential part of a much fuller, historically entrenched account of divine omnipresence, viz., tenet (1), that God is everywhere present by way of the divine essence itself being repletively present at each place. And, arguably, it is God's repletive presence by essence, that is, tenet (1) of the classical threefold schema, which is most fundamental to divine omnipresence per se. ${ }^{23}$ As Turretin (1992: 198) notes, "The orthodox believe and confess the immensity and omnipresence of God, not only as to virtue and operation, but principally as to essence."

There have, moreover, been a host of theologically motivated epistemic grounds cited in favor of tenet (1) of the classic threefold schema that remain largely overlooked or unexplored in the contemporary literature. Historically, in addition to Scripture as a source of warrant, there have been three primary theological reasons cited in favor the ubiquity of the divine essence in particular, that is, tenet (1): divine simplicity, immediate

\footnotetext{
${ }^{20}$ See Webster (2016a: 87-107) and (2016b: 115-26) for a fuller treatment of this line of thinking concerning immensity and omnipresence in particular, as well as "well-ordered thought about the divine perfections" (2016a: 97) in general.

${ }^{21}$ See Turretin (1992: 197) and Lombard (2007: bk. 1, d. 37).

${ }^{22}$ I owe this citation to Pasnau (2011b: 303).

${ }^{23}$ As Petrus van Mastricht (2019: 197, 198, my emphasis) underscores, "But as this immensity and omnipresence of God, first and foremost, concerns the essence of God, it thus also, through his essence, considers his knowledge ... and also his operation and providence," and "And when that infinity has been taken away, the omnipresence built upon cannot but fail."
} 
divine causal action at every place, and divine immensity. First, regarding divine simplicity, since the divine essence is devoid of metaphysical complexity, and if the divine power is universally operative at each place (a tenet of classical theism), then the divine essence itself is therefore wholly present at each place. ${ }^{24}$ Second, since God is immediately causally active at each place, sustaining created beings in existence, and since immediate causal action at a distance is thought to be impossible, the divine essence is therefore said to be present at each place where God is immediately causally active. ${ }^{25}$ Indeed, it is often claimed in the tradition that God's immediate causal action at a place presupposes (and thus cannot be solely constitutive of) God's presence at that place. ${ }^{26}$ Third, and what is perhaps the most commonly cited theological reason for divine omnipresence, is that divine immensity precludes the divine essence from being limited or bound to a particular locale in space. The immensity of the divine essence ad intra yields the ubiquity of the divine essence ad extra.

It is vitally important to distinguish the claim that immediate causal and epistemic relations play a crucial epistemic role in demonstrating the ubiquity of the divine essence, tenet (1) of the threefold schema, from the further claim that immediate causal relations metaphysically constitute the ubiquity of the divine essence. Many contemporary analytic philosophers and theologians who adopt a DO model of omnipresence do so on the grounds that causal and epistemic considerations have played an integral role in historical dogmatic reflection on omnipresence. While it is certainly the case that causal and epistemic relations have played an integral role in providing epistemic grounds for affirming the ubiquity of the divine essence, this does not warrant the more substantive claim that these relations metaphysically ground the ubiquity of the divine essence. This very point was underscored by Turretin (1992: 201) within the polemical context of Socinianism (whose adherents denied divine immensity as well as God's ubiquitous presence by essence, tenet (1) in favor of tenets (2) and (3)):

It is one thing to declare and demonstrate a posteriori the presence of God through the external operation; another thing to define a priori the presence of God by that operation or to maintain that God is not present except by power and operation. The former we acknowledge can rightly be done, but the latter we deny because the operation of God supposes his presence, and he must first be conceived to be and to exist before he can be conceived of as acting. Certain more modern thinkers (who limit the omnipresence of God by his operation), may be allowed their opinion if they understand it in the former sense for its manifestation a posteriori; but if they refer it to its constitution a priori, it is deservedly rejected as contrary to Scripture and approaching too near the error of the Socinians. ${ }^{27}$

Consequently, for Turretin, while it is reasonable to infer the ubiquity of the divine essence from God's immediate and universal causal operation in creation, it is problematic to define such presence solely in causal terms as this would be to omit an essential and

\footnotetext{
${ }^{24}$ For a clear example of this line of thinking in the medieval and Protestant scholastic periods see Anselm (2007: 225-6) and Mastricht (2019: 199).

${ }^{25}$ See Anselm (2007: 225-6). Aquinas argues that the principle of no immediate action at a distance applies to all agents, spiritual or corporeal, no matter how powerful (2012: Ia.Q8.a1.ad3). See also Aquinas (1975: bk.II, 68.3). Although, as Cross $(2003,2016)$ points out, this widespread principle was challenged by Duns Scotus. ${ }^{26}$ See Wesley (1991: 525) and Turretin (1992: 199, 201).

${ }^{27}$ See also Trueman (2007: 39-42) for an explication of John Owen's defense of God's ubiquitous presence by essence within the same polemical context against Socinianism.
} 
arguably more fundamental aspect of divine omnipresence. While it remains to be seen whether the fuller account of divine omnipresence in terms of the classical threefold schema is defensible, contemporary analytic theologians do well to consider its historical and theological merits.

\section{References}

Anselm (2007), Anselm: Basic Writings, trans. and ed. T. Williams, Indianapolis: Hackett.

Aquinas, T. (1975), Summa Contra Gentiles, trans. and ed. A. C. Pegis, Notre Dame: University of Notre Dame Press.

Aquinas, T. (2012), Summa Theologiae, trans. Fr. L. Shapcote, O.P., ed. J.Mortensen and E. Alarcón, Lander: The Aquinas Institute.

Arcadi, J. (2017), "God is Where God Acts: Reconceiving Divine Omnipresence," Topoi, 36 (4): 631-9.

Arminius, J. (1986), Public Disputations, in The Works of James Arminius, London edition, trans. J. Nichols, Kansas City: Beacon Hill Press.

Athanasius (1982), On the Incarnation of the Word, Crestwood: St. Vladimir's Seminary Press.

Augustine (1961), Confessions, trans. R. S. Pine-Coffin, New York: Penguin Books.

Augustine (1994), Sermons 273-305A: On the Saints, vol. III/8, trans. E. Hill, ed. J. E. Rotelle, Hyde Park: New City Press.

Augustine (2004), Letters 156-210, vol. II/3, trans. R. Teske, ed. B. Ramsey, Hyde Park: New City Press.

Bavinck, H. (2004), Reformed Dogmatics Vol 2: God and Creation, ed. John Bolt, trans. John Vriend. Grand Rapids, MI: Baker Academic.

Blount, D. K. (1997), "An Essay on Divine Presence," PhD diss., University of Notre Dame, Notre Dame.

Burn, A. E. (1918), The Athanasian Creed, 2nd ed., London: Rivingtons.

Clement of Alexandria (1885), The Stomata, or Miscellanies. Ante-Nicene Fathers: The Writings of the Fathers down to a.d. 325, trans. A. Roberts and J. Donaldson, Grand Rapids, MI: Christian Classics Ethereal Library.

Conn, C. H. (2011), "Anselmian Spacetime: Omnipresence and the Created Order," Heythrop Journal, 52 (2): 260-70.

Craig, W. L., and J. P. Moreland (2003), Philosophical Foundations for a Christian Worldview, Downers Grove, IL: InterVarsity Press.

Cross, R. (2003), "Incarnation, Omnipresence, and Action at a Distance," Neue Zeitschrift fur Systematische Theologie und Religionsphilosophie, 45 (3): 293-312.

Cross, R. (2016), “Duns Scotus on Divine Immensity," Faith and Philosophy, 33 (4): 389-413.

Cyril of Alexandria (1874), Commentary on the Gospel According to St. John, vol. 1, in A Library of Fathers of the Holy Catholic Church 43, London: Walter Smith.

Damascus, St. J. (1958), The Orthodox Faith, in Writings, The Fathers of the Church, vol. 37, trans. F. H. Chase, Washington, DC: The Catholic University of America Press.

Fuerst, A. (1951), An Historical Study of the Doctrine of the Omnipresence of God in Selected Writings between 1220-1270, Washington DC: Catholic University of America Press.

Gasser, G. (2019), "God's Omnipresence in the World: On Possible Meanings of 'en' in Panentheism,” International Journal for Philosophy of Religion, 85 (1): 43-62.

Gordon, J. R. (2018), "Rethinking Divine Spatiality: Divine Omnipresence in Philosophical and Theological Perspective," Heythrop Journal, 59 (3): 534-43. 
Goris, H. J. M. J. (2009), "Divine Omnipresence in Thomas Aquinas,” in H. J. M. J. Goris, H. Rikhof, and J. M. Schoot (eds.), Divine Transcendence and Immanence in the Work of Thomas Aquinas: A Collection of Studies Presented at the Third Conference of The Thomas Instituut Te Utrecht, December 15-17, 2005, 37-58, Leuven: Peeters.

Hoffman, J., and G. S. Rosenkrantz (2002), The Divine Attributes, Malden: Blackwell.

Hudson, H. (2009), "Omnipresence," in T. P. Flint and M. C. Rea (eds.), The Oxford Handbook of Philosophical Theology, 199-216, Oxford: Oxford University Press.

Hudson, H. (2014), The Fall and Hypertime, Oxford: Oxford University Press.

Inman, R. (2017), "Omnipresence and the Location of the Immaterial," in J. L. Kvanvig (ed.), Oxford Studies in Philosophy of Religion, vol. 8, Oxford: Oxford University Press.

Jedwab, J. (2016), “God's Omnipresence: A Defense of the Classical View," European Journal for Philosophy of Religion, 8 (2): 129-49.

Leftow, Brian (1989) “Anselm on Omnipresence," New Scholasticism, 63 (3): 326-57.

Leibniz, Gottfried Wilhelm (1989), Philosophical Papers and Letters, a selection translated and edited, with an introduction by Leroy E. Loemker, Dordrecht: Kluwer Academic.

Lombard, P. (2010), The Sentences: The Mystery of the Trinity, trans. G. Silano, Toronto: Pontifical Institute of Mediaeval Studies.

Muller, R. (2003), Post-Reformation Reformed Dogmatics, 2nd ed., Grand Rapids, MI: Baker Academic.

Oakes, R. (2006), "Divine Omnipresence and Maximal Immanence: Supernaturalism versus Pantheism," American Philosophical Quarterly, 43 (2): 171-9.

Ockham, W. (1991), Quodlibetal Questions, trans. A. J. Freddoso and F. E. Kelly, New York: Yale University Press.

Pasnau, R. (2011a), "On Existing All at Once," in C. Tapp and E. Runggaldier (eds.), God, Eternity, and Time, 11-29, Burlington: Ashgate.

Pasnau, R. (2011b), Metaphysical Themes 1274-1671, Oxford: Clarendon Press.

Poitiers, H. (1994), On the Trinity, in Hillary of Poitiers: Select Works, trans. E. W. Watson and L. Pullan, Grand Rapids, MI: Christian Classics Ethereal Library.

Pruss, A. (2013), "Omnipresence, Multilocation, the Real Presence and Time Travel," Journal of Analytic Theology, 1: 60-73.

Reynolds, P. L. (1992), “The Essence, Power, and Presence of God: Fragments of the History of an Idea, from Neopythagoreanism to Peter Abelard," in H. J. Westra (ed.), From Athens to Chartes: Neoplatonism and Medieval Thought: Studies in Honor of Edouard Jeanneau, 351-80, Leiden: Brill.

Shedd, W. G. T. (2003), Dogmatic Theology, ed. A. Gomes, New Jersey: P\&R.

Stump, E. (2010), Wandering in Darkness, New York: Oxford University Press.

Stump, E. (2013), “Omnipresence, Indwelling, and the Second Personal," European Journal for Philosophy of Religion, 4 (4): 29-53.

Stump, E. (2018), Atonement, New York: Oxford University Press.

Swinburne, R. (1993), The Coherence of Theism, New York: Oxford University Press.

Taliaferro, C. (1994), Consciousness and the Mind of God, Cambridge: Cambridge University Press.

Trueman, C. (2007), John Owen: Reformed Catholic, Renaissance Man, Burlington: Ashgate.

Turretin, F. (1992), Institutes of Elenctic Theology, vol. 2, trans. G. M. Giger, ed. J. T. Dennison, Jr., Phillipsburg: P\&R.

Van Den Brom, L. J. (1993), Divine Presence in the World: A Critical Analysis of the Notion of Divine Omnipresence, Kampen: Kok Pharos.

Van Mastricht, P. (2019), Theoretical-Practical Theology: Faith in the Triune God, vol. 2, ed. J. R. Beeke and M. T. Spangler, Grand Rapids, MI: Reformation Heritage Books. 
Wainwright, W. J. (2010), “Omnipotence, Omniscience, and Omnipresence,” in C. Taliaferro and C. Meister (eds.), The Cambridge Companion to Christian Philosophical Theology, 46-65, Cambridge: Cambridge University Press.

Webster, J. (2016a), Confessing God, London: T\&T Clark.

Webster, J. (2016b), God without Measure: Working Papers in Christian Theology, vol. 1, London: T\&T Clark.

Wesley, J. (1991), John Wesley's Sermons: An Anthology, ed. A. C. Outler and R. P. Heitzenrater, Nashville: Abingdon Press.

Wierenga, E. (1988), “Anselm on Omnipresence,” New Scholasticism, 62 (1): 30-41.

Wierenga, E. (2010), "Omnipresence," in C. Taliaferro, P. Draper, and P. L. Quinn (eds.), A Companion to Philosophy of Religion, 2nd ed., 258-62, Malden, MA: Blackwell.

Zagzebski, L. (2013), Omnisubjectivity: A Defense of a Divine Attribute, Milwaukee: Marquette University Press. 
